\title{
Clinical characteristics and risk factors associated with Pneumocystis jirovecii infection in patients with solid tumors: study of thirteen-year medical records of a large cancer center
}

Koichi Takeda', Sohei Harada ${ }^{2 *}$, Brian Hayama ${ }^{1}$, Kosuke Hoashi ${ }^{3}$, Taisuke Enokida' ${ }^{1}$ Toshiharu Sasaki ${ }^{4}$, Koh Okamoto ${ }^{5}$, Kenji Nakano ${ }^{6}$ and Daisuke Ohkushi ${ }^{1}$

\begin{abstract}
Background: Pneumocystis jirovecii pneumonia (PCP)-related risk factors among patients with solid tumors are not completely defined. Thus, we aimed to characterize PCP cases with underlying solid tumors, to highlight the factors contributing to its development besides the prolonged use of moderate-to-high dose corticosteroids.

Methods: We retrospectively reviewed the medical records of patients with solid tumors diagnosed with PCP between 2006 and 2018 at a cancer center in Tokyo, Japan. Demographic and clinical data were collected, which included malignancy types, total lymphocyte count, coexisting pulmonary disease, chemotherapy, radiation therapy, corticosteroid use, and PCP-attributable mortality.

Results: Twenty cases of PCP with solid tumors were documented in 151,718 patients and 788,914 patient-years. Lung cancer $(n=6,30 \%)$ was the most common underlying tumor, followed by breast cancer $(n=3,15 \%)$. Only six (30\%) patients were taking a dosage of $\geq 20 \mathrm{mg}$ prednisone equivalents daily for $\geq 4$ weeks from the onset of PCP. Among the remaining 14 patients, seven (50\%) had coexisting pulmonary diseases, 10 (71\%) had received chemotherapy within 90 days prior to PCP diagnosis, seven (50\%) had undergone chest radiation therapy before PCP diagnosis, seven (50\%) had received only intermittent corticosteroids, and one (7\%) received no corticosteroids. Mortality attributable to PCP was $40 \%$.

Conclusions: More than half of the patients were not taking a dosage of $\geq 20 \mathrm{mg}$ prednisone equivalents daily for $\geq 4$ weeks. Multiple other factors (e.g., lymphocytopenia, radiation to chest) may have potentially contributed to PCP in patients with solid tumors in a composite manner. We need to establish a method for estimating the likelihood of PCP taking multiple factors into account in this patient population.
\end{abstract}

Keywords: Beta-D-glucans, Corticosteroids, Invasive fungal infections, Mycoses, Solid tumors, Pneumocystis jirovecii

\footnotetext{
* Correspondence: haradas-tky@umin.ac.jp

${ }^{2}$ Department of Infection Control and Prevention, The University of Tokyo

Hospital, 7-3-1 Hongo, Bunkyo-ku, Tokyo 113-8655, Japan

Full list of author information is available at the end of the article
}

\section{$\triangle B M C$}

(c) The Author(s). 2021 Open Access This article is licensed under a Creative Commons Attribution 4.0 International License, which permits use, sharing, adaptation, distribution and reproduction in any medium or format, as long as you give appropriate credit to the original author(s) and the source, provide a link to the Creative Commons licence, and indicate if changes were made. The images or other third party material in this article are included in the article's Creative Commons licence, unless indicated otherwise in a credit line to the material. If material is not included in the article's Creative Commons licence and your intended use is not permitted by statutory regulation or exceeds the permitted use, you will need to obtain permission directly from the copyright holder. To view a copy of this licence, visit http://creativecommons.org/licenses/by/4.0/ The Creative Commons Public Domain Dedication waiver (http://creativecommons.org/publicdomain/zero/1.0/) applies to the data made available in this article, unless otherwise stated in a credit line to the data. 


\section{Background}

Pneumocystis jirovecii pneumonia (PCP) is common among patients with solid tumors. The PCP incidence in this population is approximately half of that in patients with hematological malignancies $[1,2]$. However, the risk factors for PCP in patients with solid tumors have not been well defined.

Current international guidelines recommend primary PCP prophylaxis for patients with solid tumors, when the prolonged use of a moderate-to-high corticosteroid dose (i.e., with $\geq 20 \mathrm{mg}$ prednisone equivalents daily for $\geq 4$ weeks) or when temozolomide with radiation therapy is adopted [3-5]. Nevertheless, PCP occurs without these well-known risk factors in patients treated with intensive cancer chemotherapy. The chemotherapy regimens associated with PCP occurrence include adriamycin/cyclophosphamide-containing regimen and weekly paclitaxel and trastuzumab regimen for breast cancer [6, 7], everolimus-containing regimen for breast cancer and renal cancer [8-10], FOLFIRINOX (oxaliplatin, irinotecan, leucovorin, and 5-fluorouracil) chemotherapy for pancreatic cancer [11], and gemcitabine chemotherapy for breast and pancreatic cancers [12]. Other factors such as radiation therapy $[13,14]$, intermittent courses of corticosteroids during chemotherapy (as antiemetics and/or premedication for hypersensitivity reactions) [15, 16], lymphopenia [13], coexisting pulmonary disease, and immunosuppression associated with coexisting disease (underlying disease itself or immunosuppressive therapy against the disease) may also influence PCP risk.

We aimed to characterize PCP cases with underlying solid tumors by performing a retrospective descriptive study at a cancer center, with special emphasis on cases without prolonged use of a moderate-to-high corticosteroid dose, to determine the additional PCP risk factors in these cases.

\section{Methods}

\section{Study design and settings}

This was a retrospective observational study performed at a 686-bed tertiary care cancer center in Tokyo, Japan, between January 2006 and December 2018. The center has approximately 13,000 annual admissions of patients with solid tumors.

\section{Study population and inclusion criteria}

We reviewed the medical records of all adult patients ( $\geq$ 18 years) who tested positive for Pneumocystis-specific qualitative polymerase chain reaction (PCR) performed on respiratory specimens (e.g., sputum, induced sputum, and bronchoalveolar lavage fluid) during the study period. This analysis was performed commercially at SRL Inc. (Shinjuku, Japan) by using the previously described methods as part of the diagnostic procedure in daily practice [17].

Among these patients, we selected patients with (1) a diagnosis of solid tumors, (2) pulmonary radiographic findings compatible with PCP, and a (3) plasma beta-Dglucan (BDG) (Wako Pure Chemical Industries, Tokyo, Japan) value $\geq 11 \mathrm{pg} / \mathrm{mL}$ within the 14-day period, starting 7 days prior to the day of the initial radiographic study showing pulmonary infiltrates. Plasma BDG was used to exclude cases with probable colonization of $P$. jirovecii in the respiratory tract without causing pneumonia. Patients were excluded if they had (1) concomitant hematological malignancies, (2) known Human Immunodeficiency Virus (HIV) infection, (3) received unapproved cancer drugs during PCP diagnosis, or (4) have been participating in blinded clinical trials and were unaware of the drugs they were taking. Patients were also excluded if they had conditions that are possibly associated with elevated plasma BDG levels unrelated to PCP, including (5) receiving blood components or plasma protein products (e.g., intravenous immunoglobulins, albumin), hemodialysis, or surgery within 7 days prior to plasma BDG sampling $[18,19]$ or (6) having other concomitant fungal infections, as defined by the 2008 consensus definitions of the European Organization for the Research and Treatment of Cancer/ Mycoses Study Group, within a 28-day period starting 14 days prior to the day of the plasma BDG sampling [20].

\section{Data collection}

The number of patients with solid tumors in the outpatient clinic of the hospital during the study period was extracted from the hospital database to estimate the incidence of PCP in this patient population.

The demographic and clinical data of patients diagnosed with PCP with underlying solid tumors were collected via a chart review. The data included age, sex, malignancy types, PCP prophylaxis within 90 days prior to the diagnosis of PCP, total lymphocyte count, serum lactate dehydrogenase (LDH), plasma BDG, radiological findings, coexisting pulmonary disease, past chemotherapies, time interval from the last chemotherapy to the diagnosis of $\mathrm{PCP}$, radiation of the chest (field and cumulative dose), time interval from the last radiation therapy to the diagnosis of PCP, corticosteroid use (duration and cumulative dose) within 90 days prior to PCP diagnosis, reason for corticosteroid use, pattern of corticosteroid administration (daily or intermittently), use of immunosuppressive agent within 90 days prior to PCP diagnosis, severity of $\mathrm{PCP}$, treatment regimen for PCP (choice of drugs and duration), mortality attributable to PCP, and 30-day overall mortality.

The day of PCP diagnosis was defined as the first day when relevant pulmonary infiltrates were 
documented by chest imaging. Data on total lymphocyte count and serum LDH and plasma BDG levels were collected on the day of (or the closest day within 7 days prior to) PCP diagnosis. Board-certified radiologists evaluated the chest images. Coexisting pulmonary diseases were defined as interstitial pneumonia, chronic obstructive pulmonary disease, bronchiectasis, healed pulmonary tuberculosis, primary/ metastatic lung tumors, and radiation pneumonitis. The corticosteroid dosage was expressed in prednisone equivalents (we calculated dexamethasone or betamethasone dosage of $1 \mathrm{mg}$ as equivalent to prednisone dosage of $7.5 \mathrm{mg}$ ) [21]. We included cyclophosphamide, azathioprine, mycophenolate mofetil, methotrexate, cyclosporine, and tacrolimus as immunosuppressive agents. However, if cyclophosphamide and methotrexate were used as part of a chemotherapy regimen, we did not consider them as immunosuppressive agents. Biological agents and small molecule kinase inhibitors used in the management of patients with concomitant autoimmune disorders were also considered immunosuppressive agents. PCP severity was considered "moderate to severe" in patients with arterial-alveolar difference $>35 \mathrm{mmHg}$, arterial oxygen pressure $<70 \mathrm{mmHg}$, or ambient air $\mathrm{O}_{2}$ saturation $<92 \%$. PCP severity was considered "mild" in patients not meeting these criteria. Mortality was attributed to PCP if death was due to progressive respiratory failure in a $\mathrm{PCP}$ patient.

\section{Results}

During the 13-year study period, the respiratory specimens of 48 patients tested positive for Pneumocystis-specific qualitative PCR. Among these patients, 23 patients fulfilled the inclusion criteria, but 3 of them were later excluded because they also met the exclusion criteria. Thus, a total of 20 patients were analyzed in our study (Fig. 1). During the study period, the hospital cared 151,718 patients and 788,914 patient-years with solid tumors. The calculated incidence of PCP among patients with solid tumors at the hospital was 13.2 per 100,000 patient and 2.54 per 100,000 patient-years.

Baseline and radiologic characteristics of the PCP patients The clinical characteristics of the 20 PCP patients are separately shown according to the prolonged use of a moderate-to-high corticosteroid dose (i.e., with or without a dosage $\geq 20 \mathrm{mg}$ prednisone equivalents daily for $\geq 4$ weeks) (Table 1). Fourteen (70\%) were patients without prolonged use of a moderate-to-high corticosteroid dose. Among the 20 patients, none had received primary prophylaxis for PCP. According to cancer type, lung cancer $(n=6,30 \%)$ was the most common, followed by breast cancer $(n=3,15 \%)$. The remaining 11 patients had other diverse cancer types. Eighteen patients (90\%) developed PCP while their lymphocyte counts were below 1000 cells $/ \mathrm{mm}^{3}$. Ground glass opacities, which are typical findings of PCP, were observed in 18 patients (90\%) on chest CT (Fig. 2).

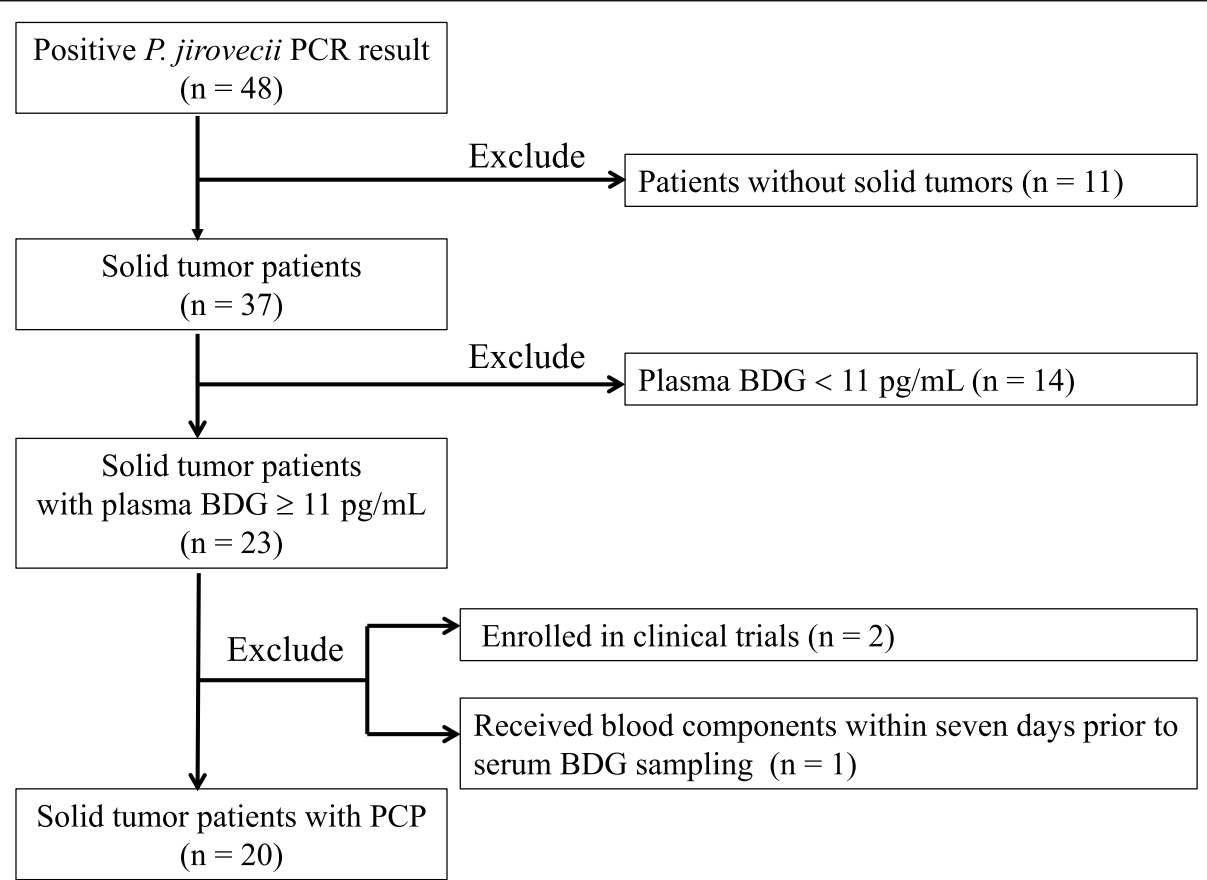

Fig. 1 Flowchart showing the inclusion and exclusion criteria applied in the selection of the study population. P. jirovecii, Pneumocystis jirovecii; PCR, polymerase chain reaction; BDG, beta-D-glucan; PCP, Pneumocystis jirovecii pneumonia 
Table 1 Clinical characteristics of the patients with $P$. jirovecii pneumonia

\begin{tabular}{|c|c|c|c|}
\hline & $\begin{array}{l}\text { Patients with prolonged use of a moderate-to-high } \\
\text { corticosteroid dose } \\
(n=6)\end{array}$ & $\begin{array}{l}\text { Patients without prolonged use of a moderate-to- } \\
\text { high corticosteroid dose } \\
(n=14)\end{array}$ & $\begin{array}{l}\text { Total } \\
(n=20)\end{array}$ \\
\hline $\begin{array}{l}\text { Age (years), median } \\
\text { (range) }\end{array}$ & $56(46-76)$ & $67(40-90)$ & $\begin{array}{l}66(40- \\
90)\end{array}$ \\
\hline \multicolumn{4}{|l|}{ Cancer type, n (\%) } \\
\hline Lung cancer & $1(17)$ & $5(36)$ & $6(30)$ \\
\hline Breast cancer & $1(17)$ & $2(14)$ & $3(15)$ \\
\hline $\begin{array}{l}\text { Esophageal } \\
\text { cancer }\end{array}$ & $0(0)$ & $2(14)$ & $2(10)$ \\
\hline Pancreatic cancer & $1(17)$ & $1(7)$ & $2(10)$ \\
\hline Others $^{a}$ & $3(50)$ & $4(29)$ & $7(35)$ \\
\hline \multicolumn{4}{|l|}{ ALC, n (\%) } \\
\hline$<500$ & $3(50)$ & $9(64)$ & $12(60)$ \\
\hline $500-999$ & $2(33)$ & $4(29)$ & $6(30)$ \\
\hline$\geq 1000$ & $1(17)$ & $1(7)$ & $2(10)$ \\
\hline \multicolumn{4}{|l|}{ LDH (Units/L) } \\
\hline$<250$ & $1(17)$ & $2(14)$ & $3(15)$ \\
\hline $250-500$ & $4(67)$ & $9(64)$ & $13(65)$ \\
\hline$>500$ & $1(17)$ & $3(21)$ & $4(20)$ \\
\hline $\begin{array}{l}\text { BDG, median } \\
\text { (range) }\end{array}$ & $85.8(19.8-522.1)$ & $37.8(16->600)$ & $\begin{array}{l}45(16-> \\
600)\end{array}$ \\
\hline \multicolumn{4}{|c|}{ Main Radiologic findings, n (\%) } \\
\hline $\begin{array}{l}\text { Ground glass } \\
\text { opacities }\end{array}$ & $5(83)$ & $13(93)$ & $18(90)$ \\
\hline Other $^{\mathrm{b}}$ & $1(17)$ & $1(7)$ & $2(10)$ \\
\hline
\end{tabular}

ALC Absolute lymphocyte count, LDH Lactate dehydrogenase, BDG Beta-D glucan, PSL Prednisolone

${ }^{a}$ Rectal cancer, thyroid cancer, and inflammatory myofibroblastic tumor with single case each in patients with PSL $\geq 20 \mathrm{mg}$ daily $\geq 4$ weeks and ovarian cancer, renal cancer, laryngeal cancer, and hypopharyngeal cancer with a single case each in patients without PSL $\geq 20 \mathrm{mg}$ daily $\geq 4$ weeks

${ }^{b}$ Examples of other findings were patchy, nodular, and focal consolidation

(a) (b)

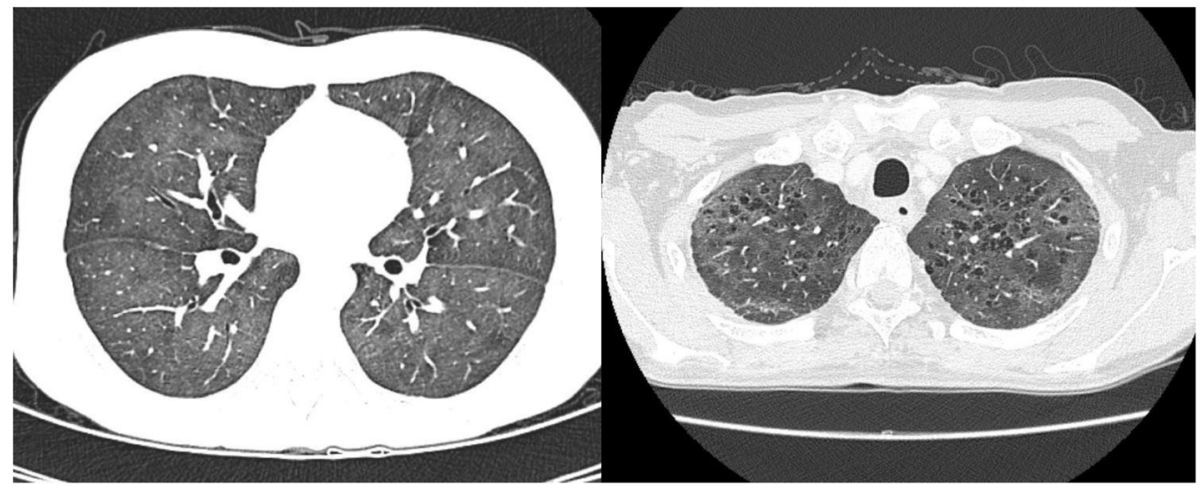

Fig. 2 Chest CT findings in patients with ground glass opacities. Patient No. 13 (a) and Patient No. 14 (b) shown in Table 3 
Table 2 Treatment outcomes for PCP

\begin{tabular}{|c|c|c|c|}
\hline & $\begin{array}{l}\text { Patients with prolonged use of a moderate-to- } \\
\text { high corticosteroid dose }(n=6)\end{array}$ & $\begin{array}{l}\text { Patients without prolonged use of a moderate-to- } \\
\text { high corticosteroid dose }(n=14)\end{array}$ & $\begin{array}{l}\text { Total } \\
(n=20)\end{array}$ \\
\hline \multicolumn{4}{|l|}{ Treatment regimen, no. (\%) } \\
\hline TMP-SMX only & $2(33)$ & $7(50)$ & $9(45)$ \\
\hline $\begin{array}{l}\text { TMP-SMX prior to } \\
\text { intravenous pentamidine }\end{array}$ & $3(50)$ & $1(7)$ & $4(20)$ \\
\hline $\begin{array}{l}\text { TMP-SMX prior to } \\
\text { atovaquone }\end{array}$ & $1(17)$ & $4(29)$ & $5(25)$ \\
\hline Atovaquone only & 0 & $2(14)$ & $2(10)$ \\
\hline \multicolumn{4}{|c|}{ Adjunctive corticosteroids, no. (\%) } \\
\hline Not used & 0 & $2(14)$ & $2(10)$ \\
\hline Newly initiated & 0 & $6(43)$ & $6(30)$ \\
\hline $\begin{array}{l}\text { Unchanged from baseline } \\
\text { dosage }\end{array}$ & $2(33)$ & 0 & $2(10)$ \\
\hline $\begin{array}{l}\text { Increased from baseline } \\
\text { dosage }\end{array}$ & $3(50)$ & $6(43)$ & $9(45)$ \\
\hline $\begin{array}{l}\text { Decreased from baseline } \\
\text { dosage }\end{array}$ & $1(17)$ & 0 & $1(5)$ \\
\hline \multicolumn{4}{|l|}{ Severity of PCP, no. (\%) } \\
\hline Mild & $2(33)$ & $7(50)$ & $9(45)$ \\
\hline Moderate to severe & $4(67)$ & $7(50)$ & $11(55)$ \\
\hline $\begin{array}{l}\text { Mortality attributed to } \mathrm{PCP} \text {, } \\
\text { no. (\%) }\end{array}$ & $5(83)$ & $3(21)$ & $8(40)$ \\
\hline Thirty-day mortality, no. (\%) & $3(50)$ & $3(21)$ & $6(30)$ \\
\hline
\end{tabular}

TMP-SMX Trimethoprim-sulfamethoxazole, PCP Pneumocystis jirovecii pneumonia

\section{Treatment outcomes of PCP}

According to the definition, 9 patients (45\%) had mild PCP, and 11 patients (55\%) had moderate to severe PCP at the time of initial presentation (Table 2). All patients received adequate initial therapy; 18 patients received trimethoprim and sulfamethoxazole (TMP-SMX), and 2 patients with mild PCP received atovaquone as a firstline therapy. Nine patients who were initially treated with TMP-SMX were switched to second-line medication (intravenous pentamidine in 4 cases and atovaquone in 5 cases) owing to the adverse effects of TMP-SMX therapy. The duration of PCP treatment was 2 to 3 weeks in all cases. Fifteen patients (75\%) received adjunctive corticosteroids (either newly initiated or increased from baseline dosage) during PCP treatment. Mortality attributable to PCP and 30-day overall mortality were $8 / 20(40 \%)$ and $6 / 20(30 \%)$, respectively.

\section{Analysis of 14 patients who developed PCP without prolonged use of a moderate-to-high corticosteroid dose}

The clinical characteristics of the 14 patients who developed PCP without prolonged use of a moderate-to-high corticosteroid dose (i.e., without $\geq 20 \mathrm{mg}$ prednisone equivalents daily for $\geq 4$ weeks) are shown in Table 3 . At the time of PCP diagnosis, 7 patients (50\%) had coexisting pulmonary diseases. Chemotherapy regimens were diverse, and no specific regimen was dominant. The number of patients receiving their last chemotherapy between 90 and 30 days prior to the diagnosis of PCP was $10(71 \%)$ and 7 (50\%), respectively. During the 90 days prior to PCP diagnosis, 6 patients $(43 \%)$ had received daily corticosteroids without fulfilling the criteria of "prolonged use of a moderate-to-high corticosteroid dose" in terms of daily dosage and/or duration, 7 patients $(50 \%)$ had received only intermittent corticosteroids, and 1 patient (7\%) had received no corticosteroids. During the 90 days prior to PCP diagnosis, only 4 patients $(29 \%)$ had received a dosage of $\geq 700 \mathrm{mg}$ prednisone equivalents as a cumulative dose. Only 1 patient (7\%) (case 11) had received immunosuppressive agents 90 days prior to PCP diagnosis. This patient had been receiving a methotrexate dosage of $10 \mathrm{mg}$ weekly for coexisting rheumatoid arthritis. Seven patients (50\%) had received radiation therapy of the chest before PCP diagnosis, and 3 patients (21\%) received therapy within 10 days.

\section{Discussion}

We characterized cases of PCP with underlying solid tumors. Twenty patients developed PCP under no primary prophylaxis. All patients had received adequate initial 
Table 3 Clinical characteristics of the 14 patients who developed PCP without prolonged moderate-to-high corticosteroid dose usage

\begin{tabular}{|c|c|c|c|c|c|c|c|c|c|c|}
\hline No & $\begin{array}{l}\text { Age } \\
\text { (years) }\end{array}$ & Sex & Cancer type & $\begin{array}{l}\text { Coexisting } \\
\text { pulmonary } \\
\text { diseases }\end{array}$ & $\begin{array}{l}\text { CTx } \\
\text { before } \\
\text { PCP } \\
\text { diagnosis }\end{array}$ & $\begin{array}{l}\text { Days } \\
\text { from last } \\
\text { CTx to } \\
\text { PCP } \\
\text { diagnosis }\end{array}$ & $\begin{array}{l}\text { Types/cumulative dose }{ }^{\text {a }} \\
\text { total days of } \\
\text { corticosteroid } \\
\text { administration within } \\
90 \text { days prior to PCP } \\
\text { diagnosis }\end{array}$ & $\begin{array}{l}\text { Reason for } \\
\text { corticosteroid } \\
\text { use }\end{array}$ & $\begin{array}{l}\text { Field/ } \\
\text { cumulative } \\
\text { dose of } \\
\text { radiation } \\
\text { therapy }\end{array}$ & $\begin{array}{l}\text { Days from } \\
\text { last } \\
\text { radiation } \\
\text { therapy to } \\
\text { PCP } \\
\text { diagnosis }\end{array}$ \\
\hline 1 & 71 & M & Lung cancer & Lung cancer & $\begin{array}{l}\text { Gefitinib } \\
\text { Erlotinib } \\
\text { CDDP/ } \\
\text { PEM/Bev } \\
\text { Gefitinib }\end{array}$ & 0 & Daily/630 mg/42 days & $\begin{array}{l}\text { Palliative } \\
\text { therapy }\end{array}$ & None & NA \\
\hline 2 & 90 & M & Renal cancer & $\mathbb{P}$ & None & NA & Daily/960 mg/68 days & $\begin{array}{l}\text { Spinal cord } \\
\text { compression }\end{array}$ & $\begin{array}{l}\text { Thoracic } \\
\text { spine/55 Gy }\end{array}$ & 61 \\
\hline 3 & 71 & M & Lung cancer & $\begin{array}{l}\text { Lung } \\
\text { cancer, } \\
\text { COPD, } \\
\text { radiation } \\
\text { pneumonitis }\end{array}$ & $\begin{array}{l}\text { CDDPNP- } \\
16\end{array}$ & 156 & Daily/560 mg/28 days & $\begin{array}{l}\text { Radiation } \\
\text { pneumonitis }\end{array}$ & Lung/39 Gy & 102 \\
\hline 4 & 64 & M & $\begin{array}{l}\text { Esophageal } \\
\text { cancer }\end{array}$ & None & $\begin{array}{l}\mathrm{CDDP} / 5- \\
\mathrm{FU}\end{array}$ & 58 & $\begin{array}{l}\text { Daily/675 mg/38 days } \\
\text { Intermittent/223 mg/4 } \\
\text { days }\end{array}$ & $\begin{array}{l}\text { Severe drug } \\
\text { allergy } \\
\text { Antiemetics/ } \\
\text { premedication } \\
\text { for CTx }\end{array}$ & $\begin{array}{l}\text { Esophagus/ } \\
60 \mathrm{~Gy}\end{array}$ & 54 \\
\hline 5 & 70 & M & $\begin{array}{l}\text { Pancreatic } \\
\text { cancer }\end{array}$ & None & $\begin{array}{l}\text { GEM/ } \\
\text { nabPTX }\end{array}$ & 13 & $\begin{array}{l}\text { Daily/630 mg/42 days } \\
\text { Intermittent/248 mg/5 } \\
\text { days }\end{array}$ & $\begin{array}{l}\text { Palliative } \\
\text { therapy } \\
\text { Antiemetics/ } \\
\text { premedication } \\
\text { for CTx }\end{array}$ & None & NA \\
\hline 6 & 64 & M & Lung cancer & $\begin{array}{l}\text { Lung } \\
\text { cancer, } \\
\text { radiation } \\
\text { pneumonitis }\end{array}$ & CDDP/S-1 & 107 & Daily/405 mg/20 days & $\begin{array}{l}\text { Radiation } \\
\text { pneumonitis }\end{array}$ & Lung/60 Gy & 94 \\
\hline 7 & 59 & $\mathrm{~F}$ & Ovarian cancer & None & $\begin{array}{l}\text { CBDCA } \\
\text { PTX DOC }\end{array}$ & 33 & $\begin{array}{l}\text { Intermittent/120 mg/2 } \\
\text { days }\end{array}$ & $\begin{array}{l}\text { Antiemetics/ } \\
\text { premedication } \\
\text { for CTx }\end{array}$ & None & NA \\
\hline 8 & 60 & M & $\begin{array}{l}\text { Esophageal } \\
\text { cancer }\end{array}$ & None & $5-\mathrm{FU}$ & 11 & $\begin{array}{l}\text { Intermittent/446 mg/8 } \\
\text { days }\end{array}$ & $\begin{array}{l}\text { Antiemetics/ } \\
\text { premedication } \\
\text { for CTx }\end{array}$ & $\begin{array}{l}\text { Esophagus/ } \\
58 \mathrm{~Gy}\end{array}$ & 0 \\
\hline 9 & 68 & $\mathrm{~F}$ & Breast cancer & None & $\mathrm{ADR} / \mathrm{CY}$ & 15 & $\begin{array}{l}\text { Intermittent/387 mg/12 } \\
\text { days }\end{array}$ & $\begin{array}{l}\text { Antiemetics/ } \\
\text { premedication } \\
\text { for CTx }\end{array}$ & None & NA \\
\hline 10 & 67 & M & Lung cancer & Lung cancer & $\begin{array}{l}\text { CBDCA/ } \\
\text { PTX }\end{array}$ & 98 & None & NA & Lung/66 Gy & 9 \\
\hline 11 & 67 & M & Laryngeal cancer & $\begin{array}{l}\text { Metastatic } \\
\text { lung cancer }\end{array}$ & PTX/Cet & 14 & $\begin{array}{l}\text { Intermittent/495 mg/10 } \\
\text { days }\end{array}$ & $\begin{array}{l}\text { Antiemetics/ } \\
\text { premedication } \\
\text { for CTx }\end{array}$ & None & NA \\
\hline 12 & 72 & M & Lung cancer & Lung cancer & $\begin{array}{l}\text { CBDCA } \\
\text { PTX }\end{array}$ & 64 & $\begin{array}{l}\text { Intermittent/248 mg/2 } \\
\text { days }\end{array}$ & $\begin{array}{l}\text { Antiemetics/ } \\
\text { premedication } \\
\text { for CTx }\end{array}$ & Lung/52 Gy & 3 \\
\hline 13 & 40 & $\mathrm{~F}$ & Breast cancer & None & $\begin{array}{l}\mathrm{CY} / \mathrm{EPI} / 5- \\
\mathrm{FU} \\
\mathrm{DOC} / \mathrm{HER}\end{array}$ & 12 & $\begin{array}{l}\text { Intermittent/932 mg/14 } \\
\text { days }\end{array}$ & $\begin{array}{l}\text { Antiemetics/ } \\
\text { premedication } \\
\text { for CTx }\end{array}$ & None & NA \\
\hline 14 & 58 & M & $\begin{array}{l}\text { Hypopharyngeal } \\
\text { cancer }\end{array}$ & None & $\begin{array}{l}\text { CDDP } \\
\text { PTX/Cet }\end{array}$ & 5 & $\begin{array}{l}\text { Intermittent/396 mg/8 } \\
\text { days }\end{array}$ & $\begin{array}{l}\text { Antiemetics/ } \\
\text { premedication } \\
\text { for CTx }\end{array}$ & None & NA \\
\hline
\end{tabular}

PCP Pneumocystis jirovecii pneumonia, CTx Chemotherapy, $M$ Male, $F$ Female, IP Interstitial pneumonia, COPD Chronic obstructive pulmonary disease, CDDP Cisplatin, PEM Pemetrexed, Bev Bevacizumab, VP-16 Etoposide, 5-FU 5-fluorouracil, GEM Gemcitabine, nabPTX Nab-paclitaxel, S-1 TS-1, CBDCA Carboplatin, PTX Paclitaxel, DOC Docetaxel, ADR Adriamycin, CY Cyclophosphamide, Cet Cetuximab, EPI Epirubicin, HER Trastuzumab, Gy Gray, NA Not available

${ }^{a}$ The dosage of cumulative corticosteroids was expressed in prednisone equivalents 
therapy, and mortality attributable to PCP and 30-day overall mortality were 40 and $30 \%$ respectively.

During the 13-year study period, 14 patients developed PCP without prolonged use of a moderate-to-high corticosteroid dose. The mortality from PCP in patients without HIV infection is generally higher than that in HIV-infected patients ( 35-50\%) [22-24]. The prognostic benefit of adjunctive use of corticosteroid, which is well established in PCP in patients with HIV, is uncertain in this patient population [25]. In the current study, the mortality attributable to PCP was $40 \%$, which was similar to previous reports. By taking the high mortality into account, we sought to identify the group of patients with nonnegligible PCP risk among noncandidates for primary prophylaxis under the current guidelines. Thus, we described in detail the background of 14 patients who met these criteria.

In the 14 patients, lung cancer $(n=5,36 \%)$ was the most common, followed by breast $(n=2,14 \%)$ and esophageal $(n=2,14 \%)$ cancers. In a study at a cancer center, primary and metastatic brain tumors were the most common among patients with PCP in the presence of solid tumors [26], followed by lung and breast cancers; this is similar to the findings of the present study. Here, no patient had brain tumors diagnosed with PCP because of the lack of a neurosurgery department at the hospital. There was no predominance of any specific chemotherapy, but many patients $(n=10,71 \%)$ received chemotherapy within 90 days. A previous study of $80 \mathrm{PCP}$ episodes in cancer patients revealed that chemotherapy or immunosuppressive drugs had been administered in 50 episodes (63\%) within 1 month prior to PCP diagnosis [27]. The recent administration of cancer chemotherapy may be a risk factor for PCP development.

In this study, 7 (50\%) of the 14 patients had received chest radiation therapy. In particular, case 10 (lung cancer) received chest radiation therapy (66 Gy totally) within 9 days prior to PCP diagnosis and had no history of cancer chemotherapy or corticosteroid use within 90 days. Therefore, it is presumed that radiation therapy contributed significantly to PCP onset in this patient. In a previous study of 26 patients who developed PCP with underlying solid tumors and lymphomas, 22 patients $(85 \%)$ had a history of irradiation [13]. Thoracic duct irradiation may contribute to lymphopenia, with radiation therapy at the mediastinal area considered a PCPpredisposing factor [13]. A study of PCP patients with lung cancer also concluded that concurrent chemoradiotherapy was a risk factor for PCP development [14]. Therefore, it may be necessary to consider radiation therapy (particularly for the thorax/lung/mediastinum) as a PCP risk factor.

PCP occurred not only in patients receiving daily corticosteroids but also in seven patients (50\%) receiving only intermittent courses of corticosteroids as an antiemetic and/or premedication for hypersensitivity reactions during chemotherapy. In a previous study of 128 HIV-uninfected PCP patients, 50 patients (43\%) received intermittent corticosteroids only [16]. It is essential to recognize that PCP can develop in such treatment backgrounds. The risk of infectious disease increased when the cumulative dose of daily corticosteroids exceeded $700 \mathrm{mg}$ (prednisone equivalent) [28]. However, it is unknown whether this threshold can be applied to the cumulative dose of intermittent corticosteroid administration. In fact, among the 7 patients who developed PCP on intermittent corticosteroids, only 1 (case 13) had exceeded a cumulative dose of $700 \mathrm{mg}$ (prednisone equivalent) within 90 days prior to PCP diagnosis. Future studies are required to evaluate the quantitative effect of intermittent corticosteroids on PCP development. Among the 14 patients without prolonged use of a moderate-to-high corticosteroid dose, all but 1 patient (93\%) had a lymphocyte count of less than 1000 cells/ $\mathrm{mm}^{3}$, while 9 patients (64\%) had fewer than 500 cells/ $\mathrm{mm}^{3}$. In a previously mentioned study of 26 patients who developed PCP with underlying solid tumors and lymphomas, 18 patients $(69 \%)$ had a lymphocyte count of less than 1000 cells $/ \mathrm{mm}^{3}$, while 9 patients (35\%) had fewer than 500 cells $/ \mathrm{mm}^{3}$ [13]. These data suggest that lymphopenia may be a PCP risk factor. Among the 14 patients without prolonged use of a moderate-to-high corticosteroid dose, 7 patients $(n=7,50 \%)$ had coexisting pulmonary diseases. A study of PCP in patients with rheumatoid arthritis who were receiving infliximab therapy, revealed that the presence of coexisting pulmonary disease was one of the PCP risk factors [29]. The spectrum of coexisting pulmonary diseases that contributes to PCP development and their effects remains to be elucidated.

There are several limitations to this study. First, the study included only patients tested with Pneumocystisspecific PCR. Owing to the nature of the retrospective study, all suspected PCP patients may not have undergone PCR testing, thus possibly leading to the inclusion of fewer PCP patients than the actual number of cases. However, the incidence rate of PCP among patients with solid tumors here was similar to that among lung or breast cancer patients in a previous report [1]. Therefore, we believe that there is no major undercounting of PCP patients in our cancer center. Second, our study relied heavily on conventional PCR (c-PCR) and plasma BDG for PCP diagnosis because of the lack of commercially available real-time PCR in Japan. Although c-PCR has low specificity in diagnosing PCP because it cannot distinguish colonization from infection; the sensitivity was reported as high as $90 \%$ (equivalent to/higher than that of qPCR) [30]. Therefore, we postulated that c-PCR 
would be suitable for screening patients. Furthermore, given that the specificity of plasma BDG $\geq 11 \mathrm{pg} / \mathrm{mL}$ for diagnosing PCP was reported to be very high (98-100\%) in selected situations [31, 32] and that this study carefully excluded the known factors that increase plasma BDG levels other than PCP, we assume that the PCP cases in the present study reflect actual cases. Lastly, the lack of controls prevented the statistical assessment of individual factors that may have contributed to PCP development. In addition, since this is a single-center study with a limited number of cases, further research is needed to determine whether the observed results are applicable in different settings.

\section{Conclusions}

Most patients with solid tumors who developed PCP were not taking a moderate-to-high corticosteroid dose for prophylaxis. Multiple factors that are not currently recognized as stand-alone risk factors probably contribute to PCP development in a composite manner are types of solid tumors, recent administration of cancer chemotherapy, chest radiation therapy, low-dose or intermittent corticosteroids and other immunosuppressive drugs, lymphocyte count, and coexisting pulmonary diseases. As stated in latest guidelines, universal prophylaxis of PCP in these patients is not recommended, given the low incidence [5]. Nevertheless, we need to establish a method for estimating the likelihood of PCP taking multiple factors into account in patients with solid tumors with newly appearing pulmonary infiltrates.

\section{Abbreviations \\ PCP: Pneumocystis jirovecii pneumonia; FOLFIRINOX: Oxaliplatin, Irinotecan, Leucovorin, and 5-Fluorouracil; PCR: Polymerase Chain Reaction; BDG: Beta- D-Glucan; HIV: Human Immunodeficiency Virus; LDH: Lactate Dehydrogenase; TMP-SMX: Trimethoprim and Sulfamethoxazole; c-PCR: Conventional \\ Polymerase Chain Reaction; qPCR: Quantitative Polymerase Chain Reaction}

\section{Acknowledgments}

Not applicable.

\section{Authors' contributions}

$\mathrm{KT}$ conceptualized the study, designed the methods, conducted the investigations, performed quality control of data and algorithms, conducted formal analysis, drafted, edited and reviewed the manuscript. SH conceptualized the study, designed the methods, conducted the investigations, performed quality control of data and algorithms, conducted formal analysis, drafted, edited and reviewed the manuscript. BH conducted the investigations, drafted, edited and reviewed the manuscript. $\mathrm{KH}$ conducted the investigations, drafted, edited and reviewed the manuscript TE conducted the investigations, drafted, edited and reviewed the manuscript. TS conducted the investigations, drafted, edited and reviewed the manuscript. $\mathrm{KO}$ edited and reviewed the manuscript. KN performed quality control of data and algorithms, drafted, edited and reviewed the manuscript. DO conducted the investigations, drafted, edited and reviewed the manuscript. All the authors are accountable for all aspects of the study and have approved the final manuscript.

\section{Funding}

This research did not receive any specific grant from funding agencies in the public, commercial, or not-for-profit sectors.
Availability of data and materials

All supporting information can be found in the tables in the article.

\section{Declarations}

\section{Ethics approval and consent to participate}

The study was approved by the Ethics Committee of Cancer Institute Hospital, Japanese Foundation for Cancer Research prior to initiation (approval number: 2019-1018). All procedures were in accordance with the 1964 Declaration of Helsinki and its later amendments or with comparable ethical standards. Informed consent for this retrospective, noninvasive study was not required by the local ethics committee. The local ethics committee permitted to access the raw data from the hospital database.

\section{Consent for publication}

Not applicable.

\section{Competing interests}

SH has received honoraria from MSD, Shionogi, Astellas, BD, Beckman Coulter Diagnostics, Sumitomo Dainippon Pharma, and Meiji; has served in a consultancy/ advisory role for FUJFFILM Toyama Chemical; and has received research funding from MSD, outside the submitted work. BH has received honoraria from Janssen Pharmaceutica, outside the submitted work. DO has received Honoraria from Sumitomo Dainippon, outside the submitted work. All other authors have no conflicts of interest to declare.

\section{Author details}

'Department of Infectious Diseases, Cancer Institute Hospital, Japanese Foundation for Cancer Research, 3-8-31 Ariake, Koto-ku, Tokyo 135-8550, Japan. ${ }^{2}$ Department of Infection Control and Prevention, The University of Tokyo Hospital, 7-3-1 Hongo, Bunkyo-ku, Tokyo 113-8655, Japan. ${ }^{3}$ Department of Infectious Diseases, lizuka Hospital, 3-83 Yoshio-machi, lizuka, Fukuoka 820-8505, Japan. ${ }^{4}$ Department of Infectious Diseases, Fujita Health University School of Medicine, 1-98 Dengakugakubo, Kutsukake-cho, Toyoake, Aichi 470-1192, Japan. ${ }^{5}$ Department of Infectious Diseases, The University of Tokyo Hospital, 7-3-1 Hongo, Bunkyo-ku, Tokyo 113-8655, Japan. ${ }^{6}$ Department of Medical Oncology, Cancer Institute Hospital, Japanese Foundation for Cancer Research, 3-8-31 Ariake, Koto-ku, Tokyo 135-8550, Japan.

Received: 21 October 2020 Accepted: 26 August 2021

Published online: 03 September 2021

\section{References}

1. Fillatre P, Decaux O, Jouneau S, Revest M, Gacouin A, Robert-Gangneux F, et al. Incidence of pneumocystis jiroveci pneumonia among groups at risk in HIV-negative patients. Am J Med. 2014;127(1242):e11-7. https://doi.org/10.1 016/j.amjmed.2014.07.010.

2. Roblot F, Le Moal G, Kauffmann-Lacroix C, Bastides F, Boutoille D, Verdon R, et al. Pneumocystis jirovecii pneumonia in HIV-negative patients: a prospective study with focus on immunosuppressive drugs and markers of immune impairment. Scand J Infect Dis. 2014;46(3):210-4. https://doi.org/1 0.3109/00365548.2013.865142.

3. Taplitz RA, Kennedy EB, Bow EJ, Crews J, Gleason C, Hawley DK, et al. Antimicrobial prophylaxis for adult patients with cancer-related immunosuppression: ASCO and IDSA clinical practice guideline update. J Clin Oncol. 2018;36(30):3043-54. https://doi.org/10.1200/JCO.18.00374.

4. NCCN Clinical Practice Guidelines in Oncology Prevention and Treatment of Cancer-Related Infections. National Comprehensive Cancer Network. Version 1. 2020 https://www.nccn.org/professionals/physician_gls/pdf/infections.pdf. Accessed on Oct 18, 2020.

5. Classen AY, Henze L, von Lilienfeld-Toal M, Maschmeyer G, Sandherr M, Graeff LD, et al. Primary prophylaxis of bacterial infections and pneumocystis jirovecii pneumonia in patients with hematologic malignancies and solid tumors: 2020 updated guidelines of the infectious diseases working Party of the German Society of hematology and medical oncology (AGIHO/DGHO). Ann Hematol. 2021;100(6):1603-20. https://doi. org/10.1007/s00277-021-04452-9.

6. Waks AG, Tolaney SM, Galar A, Arnaout A, Porter JB, Marty FM, et al. Pneumocystis jiroveci pneumonia (PCP) in patients receiving neoadjuvant and adjuvant anthracycline-based chemotherapy for breast cancer: 
incidence and risk factors. Breast Cancer Res Treat. 2015;154(2):359-67. https://doi.org/10.1007/s10549-015-3573-2.

7. Kim S, Bordeleau L, Tannock IF, Rotstein C. A fatal case of pneumocystis jirovecii pneumonia in a breast cancer patient receiving weekly paclitaxel and trastuzumab. J Oncol Pharm Pract. 2012;18(2):293-5. https://doi.org/1 $0.1177 / 1078155211412991$

8. Ray A, Khong B, Khong HT. A case report of Pneumocystis jiroveci pneumonia in a patient with metastatic breast cancer. Anticancer Res. 2016; 36:6673-6. https://doi.org/10.21873/anticanres.11277.

9. Loron MC, Grange S, Guerrot D, Di Fiore F, Freguin C, Hanoy M, et al. Pneumocystis jirovecii pneumonia in everolimus-treated renal cell carcinoma. J Clin Oncol. 2015;33(8):e45-7. https://doi.org/10.1200/JCO.2013.49.9277.

10. Saito $Y$, Nagayama M, Miura Y, Ogushi S, Suzuki Y, Noro R, et al. A case of pneumocystis pneumonia associated with everolimus therapy for renal cell carcinoma. Jpn J Clin Oncol. 2013;43(5):559-62. https://doi.org/10.1093/jico/ hyt019.

11. Péron J, Derbel O, Penet A-S, Stella M, Méeus P, Orlandini F, et al. Concomitant occurrence of pulmonary invasive aspergillosis and pneumocystis pneumonia during FOLFIRINOX chemotherapy for pancreatic carcinoma. Pancreas. 2013;42(1):178-80. https://doi.org/10.1097/MPA.0b013 e31825486f8.

12. Lingaratnam SM, Slavin MA, Thursky KA, Teh BW, Haeusler GM, Seymour JF, et al. Pneumocystis jirovecii pneumonia associated with gemcitabine chemotherapy: experience at an Australian center and recommendations for targeted prophylaxis. Leuk Lymphoma. 2015;56(1):157-62. https://doi. org/10.3109/10428194.2014.911861.

13. Barbounis V, Aperis G, Gambletsas E, Koumakis G, Demiris M, Vassilomanolakis $\mathrm{M}$, et al. Pneumocystis carinii pneumonia in patients with solid tumors and lymphomas: predisposing factors and outcome. Anticancer Res. 2005;25(1B):651-5.

14. Lee EH, Kim EY, Lee SH, Roh YH, Leem AY, Song JH, et al. Risk factors and clinical characteristics of pneumocystis jirovecii pneumonia in lung cancer. Sci Rep. 2019;9(1):2094. https://doi.org/10.1038/s41598-019-38618-3.

15. Hesketh PJ, Kris MG, Basch E, Bohlke K, Barbour S, Clark-Snow RA, et al. Antiemetics: American Society of Clinical Oncology clinical practice guideline update. J Clin Oncol. 2017;35(28):3240-61. https://doi.org/10.1200/ JCO.2017.74.4789.

16. Calero-Bernal ML, Martin-Garrido I, Donazar-Ezcurra M, Limper AH, Carmona EM. Intermittent courses of corticosteroids also present a risk for pneumocystis pneumonia in non-HIV patients. Can Respir J. 2016;2016: 2464791-7. https://doi.org/10.1155/2016/2464791.

17. Wakefield AE, Pixley FJ, Banerji S, Sinclair K, Miller RF, Moxon ER, et al. Detection of pneumocystis carinii with DNA amplification. Lancet. 1990; 336(8713):451-3. https://doi.org/10.1016/0140-6736(90)92008-6.

18. Held J, Wagner D. $\beta$-D-glucan kinetics for the assessment of treatment response in pneumocystis jirovecii pneumonia. Clin Microbiol Infect. 2011; 17(7):1118-22. https://doi.org/10.1111/j.1469-0691.2010.03452.x.

19. Szyszkowitz A, Zurl C, Herzeg A, Berger A, Gemes G, Mitteregger M, et al. Serum 1,3-Beta-D-Glucan values during and after laparoscopic and open intestinal surgery. Open Forum Infect Dis. 2018;5:ofy296. https://doi.org/10.1 093/ofid/ofy296.

20. De Pauw B, Walsh TJ, Donnelly JP, Stevens DA, Edwards JE, Calandra T, et al. Revised definitions of invasive fungal disease from the European Organization for Research and Treatment of Cancer/invasive fungal infections cooperative group and the National Institute of Allergy and Infectious Diseases mycoses study group (EORTC/MSG) consensus group. Clin Infect Dis. 2008;46(12):1813-21. https://doi.org/10.1086/588660.

21. Liu D, Ahmet A, Ward L, Krishnamoorthy P, Mandelcorn ED, Leigh R, et al. A practical guide to the monitoring and management of the complications of systemic corticosteroid therapy. Allergy Asthma Clin Immunol. 2013;9(1):30 https://doi.org/10.1186/1710-1492-9-30.

22. Mansharamani NG, Garland R, Delaney D, Koziel H. Management and outcome patterns for adult pneumocystis carinii pneumonia, 1985 to 1995: comparison of HIV-associated cases to other immunocompromised states. Chest. 2000;1 18(3):704-11. https://doi.org/10.1378/chest.118.3.704.

23. Yale SH, Limper AH. Pneumocystis carinii pneumonia in patients without acquired immunodeficiency syndrome: associated illnesses and prior corticosteroid therapy. Mayo Clin Proc. 1996;71(1):5-13. https://doi.org/10.4 065/71.1.5.
24. Kovacs JA, Hiemenz JW, Macher AM, Stover D, Murray HW, Shelhamer J, et al. Pneumocystis carinii pneumonia: a comparison between patients with the acquired immunodeficiency syndrome and patients with other immunodeficiencies. Ann Intern Med. 1984;100(5):663-71. https://doi.org/10. 7326/0003-4819-100-5-663.

25. Assal M, Lambert J, Chow-Chine L, Bisbal M, Servan L, Gonzalez F, et al. Prognostic impact of early adjunctive corticosteroid therapy in non-HIV oncology or haematology patients with pneumocystis jirovecii pneumonia: a propensity score analysis. PLoS One. 2021;16(4):e0250611. https://doi.org/1 0.1371/journal.pone.0250611

26. Sepkowitz KA, Brown AE, Telzak EE, Gottlieb S, Armstrong D. Pneumocystis carinii pneumonia among patients without AIDS at a cancer hospital. JAMA. 1992;267(6):832-7. https://doi.org/10.1001/jama.1992.03480060078034.

27. Torres HA, Chemaly RF, Storey R, Aguilera EA, Nogueras GM, Safdar A, et al. Influence of type of cancer and hematopoietic stem cell transplantation on clinical presentation of pneumocystis jiroveci pneumonia in cancer patients. Eur J Clin Microbiol Infect Dis. 2006;25(6):382-8. https://doi.org/10.1007/s1 0096-006-0149-4.

28. Stuck AE, Minder CE, Frey FJ. Risk of infectious complications in patients taking glucocorticosteroids. Rev Infect Dis. 1989;11(6):954-63. https://doi. org/10.1093/clinids/11.6.954.

29. Harigai M, Koike R, Miyasaka N. Pneumocystis pneumonia under anti-tumor necrosis factor therapy (PAT) study group. Pneumocystis pneumonia associated with infliximab in Japan. N Engl J Med. 2007;357(18):1874-6. https://doi.org/10.1056/NEJMc070728.

30. Fujisawa T, Suda T, Matsuda H, Inui N, Nakamura Y, Sato J, et al. Real-time $P C R$ is more specific than conventional PCR for induced sputum diagnosis of pneumocystis pneumonia in immunocompromised patients without HIV infection. Respirology. 2009;14(2):203-9. https://doi.org/10.1111/j.1440-1 843.2008.01457.x.

31. Dichtl K, Seybold U, Wagener J. Evaluation of a turbidimetric $\beta$-D-glucan test for detection of pneumocystis jirovecii pneumonia. J Clin Microbiol. 2018;56(7):e00286-18. https://doi.org/10.1128/JCM.00286-18.

32. Mercier T, Guldentops E, Patteet S, Beuselinck K, Lagrou K, Maertens J. BetaD-glucan for diagnosing pneumocystis pneumonia: a direct comparison between the Wako $\beta$-glucan assay and the Fungitell assay. J Clin Microbiol. 2019;57(6):e00322-19. https://doi.org/10.1128/JCM.00322-19.

\section{Publisher's Note}

Springer Nature remains neutral with regard to jurisdictional claims in published maps and institutional affiliations.

Ready to submit your research? Choose BMC and benefit from:

- fast, convenient online submission

- thorough peer review by experienced researchers in your field

- rapid publication on acceptance

- support for research data, including large and complex data types

- gold Open Access which fosters wider collaboration and increased citations

- maximum visibility for your research: over $100 \mathrm{M}$ website views per year

At BMC, research is always in progress.

Learn more biomedcentral.com/submissions 